\title{
Assessment Of Availability Of Visual Inspection With Acetic - Acid (VIA) Requirements For Cervical Cancer Screening In Secondary Health Care Institutions Of Kaduna State, Nigeria.
}

\author{
Musa, $\mathrm{U}^{1}$, Balarabe, $\mathrm{F}^{2}$, Chado, M.A ${ }^{1}$, Ladan, M.A ${ }^{2}$, and Sani, D.K ${ }^{2}$ \\ 1. Department of Physical and Health Education, Faculty of Education, Ahmadu Bello University, Zaria. \\ 2. Department of Nursing Science, Faculty of Medicine, Ahmadu Bello University Zaria.
}

\begin{abstract}
The study determined the availability of visual inspection with acetic-acid requirements for cervical cancer screening in secondary health care institutions of Kaduna state. A cross-sectional descriptive survey was used for the study. The study population comprises all nurses, midwives, and nurse-midwives working in all the secondary healthcare institutions of the state. The sample size used for the study was 300 using the Yamane sample size selection formula. The technique involved was stratified sampling method whereby the three existing senatorial zones served as strata. Each of the stratum was clustered according to the existing local government areas. A purposive sampling was further used to select nine local governments, three from each senatorial zone that have secondary health care institutions. A proportionate sampling was used to distribute questionnaire copies to the health workers. The instrument used for data collection was a questionnaire which has been modified to four point likert scale. Three hundred (300) questionnaire copies were administered out of which (297) were retrieved. The data collected was analyzed using one way analysis of variance (ANOVA) at 0.05 level of confidence to answer the hypotheses. A post-hoc scheffe test was further used to determine were the differences are. Findings from the study shows that VIA requirements are not available in the secondary health care institutions for cervical cancer screening with an aggregate mean score of (2.1458). There is a significant difference among the secondary health care institutions in the availability of VIA requirements to screen for cervical cancer in Kaduna state where $(P<0.05)$. It is therefore recommended that the hospital management board should make provision of VIA requirements so that they can be available in the institutions for VIA screening services.
\end{abstract}

Key words: Availability, Visual Inspection, Acetic-acid, Requirements, Secondary healthcare institutions.

\section{Introduction}

Worldwide, it is reported that cervical cancer is the second most common and the fifth deadliest disease in women. It affects about 16 per 100,000 women per year and kills about 9 per 100,000 per year. Approximately, $80 \%$ of cervical cancer occur in developing countries . Globally, in 2008, it was estimated that there were 473,000 cases of cervical cancer, and 253,500 deaths per year (Dim, 2012). According to a report of Alliance for Cervical Cancer Prevention (ACCP) (2004), the regions hardest hit by cervical cancer are among the worlds poorest regions which are in Central and South America, the Caribbean, sub-Saharan Africa and parts of Asia. Ferley, Bray, Pisani and Parkin (2013) earlier stated that approximately 1.4 million women worldwide are living with cervical cancer, up to 7 million women worldwide may have precancerous condition that needs to be identified and treated early. Recent years have witnessed a significant development in cervical cancer prevention in developed countries in addition to cytology screening services. Previous efforts to implement cytology-based screening in developing countries have been conducted in the early 1980's but it has failed to reduce the mortality rates, mainly due to inadequate material resources, and lack of trained providers. In this regard, a recent cost-effective screening strategy using VIA emerged to be use, in developing countries like Nigeria.

Ibrahim, Rasch, Pukkala and Aro (2004) reported that cervical cancer screening based on cytological examination is largely unavailable in developing countries or available only to a small, select group of women in private facilities, maternal and child health sites, or family planning clinics, thereby missing the age groups at the highest risk for precancerous lesions. According to Evaluation of Cervical Cancer in Nigeria (2013), the failure of a conventional cytology-based approach to reducing cervical cancer in developing countries, particularly in Africa, can be attributed to several factors including scarcity of trained skilled professionals, lack of resources and expense. Therefore, an interest in a new screening method using visual techniques to identify cervical cancer developed. The technique involved is the simple screening method, that is visual screening by use of acetic acid (VIA), during which the cervix is visualized with the naked eye under a direct source of light and application of a solution of 3\% - 5\% acetic and that is used as a chemical contrast agent to highlight areas of 
metaplastic changes is a malignant change in the aceto-white area in the cervix, which is precisely around the squamo-columnar junction, the main anatomical site where cervical malignant neoplasia develops.

USAID (2010) stated that the choice of screening test usually depends on the resources available. Many developing countries are now using the single visit approach which combines detection of lesions using visual inspection with acetic acid (ordinary vinegar) followed by immediate treatment if necessary. Gaffikin, Mcgrath, Arbyn, Blumenthal (2007) stated that cervical cancer, the second most commonly diagnosed cancer among women worldwide, can be a preventable disease. Although the pap smear remains the most common screening test for cervical cancer, many developing countries may not have adequate resources to implement cytology-based prevention programmes. An alternative, low-cost test, visual inspection using acetic acid (VIA), has emerged for use in developing countries, Nigeria inclusive where the resources may or may not be available.

Gupta(2011) stated that the cost factor on testing for human papilloma virus (HPV) using DNA testing, coupled with requirement of trained manpower makes the option non-viable for developing countries, thus, accentuating the need for alternative screening procedures. Visual inspection using acetic acid (VIA) has emerged as a promising cost-effective, non-cytology-based, 'see and treat' alternative for economically developing geographic regions where it is available. Globally, decrease uptake of cervical cancer screening is predominantly a problem of developing countries, due to limited access to screening facilities, thereby leading to the high increased in the number of women who come up with cervical cancer. The extent to which the number of women diagnosed with cervical cancer keep on increasing has remained a matter of grave concern to the present researchers that a study on availability of Visual Inspection With Acetic Acid (VIA) requirements in the secondary healthcare institutions of Kaduna -state is therefore considered desirable with a view to increase the deliverance of screening programmes and subsequently the decline of cervical cancer.

\section{Hypothesis}

A null-hypothesis is stated below stating that:

There is no significant difference among the secondary healthcare institutions in the provision of available VIA requirements for cervical cancer screening in Kaduna State.

\section{Methods}

A cross-sectional survey design was used for the study. The research population comprises of all Nurses working in secondary healthcare institutions of Kaduna state. According to the State Ministry of Health (2013), the distribution of Nurses working in the secondary healthcare institutions of the state are 1,081. The use of nurses for this study is justified by the fact that the innovation of VIA is to increase the up-take of cervical cancer screening in developing countries, at primary and secondary health care institutions, also nursing staff have the highest percentage of workers among the health workers of Kaduna- state, they monitor the condition of patients for 24hours and are therefore in a better position to respond to questions that will be raise on availability of VIA requirements to screen for cervical cancer. The sample size used was 300 based on Yamane, (1967) sample size formula. A stratified sampling was used to select the existing senatorial zones of Kaduna, into northern, central and southern zones. Each stratum of the senatorial zone served as clustered according to the present existing local government areas.

A purposive sampling was used to select nine (9) local government areas (Kaduna- South, KadunaNorth,Birnin-Gwari, Ikara, Zaria, Sabon-Gari, Kauru, Jama'a and Kachi'a) that have secondary healthcare institutions. As such, the purposely selected secondary healthcare institutions were (Barau Dikko specialist hospital, Yusuf Dantsoho memorial hospital, Jibril mai-gwari memorial hospital, General hospital Ikara, Gambo-Sawaba memorial hospital Zaria, Major Ibrahim memorial hospital Sabon-Gari, General hospital Kachia) served as the sampling frame from which the sample of 300 nurses was drawn. Proportionate sampling was used at the secondary healthcare institutions to distribute questionnaires to the health workers based on their number in each hospital (see table 4 below). The health workers available were given copies of the questionnaire to fill at the selected secondary healthcare institutions, this was employ because the researchers can easily reach out to the respondents at their various work locations. Questionnaire designed by the researchers was the instrument used for data collection. The responses to the items of the questionnaire were measured on a four point interval scale. The scale was patterned along Likert format of Strongly Agree (SA) = 4 , Agree $(A)=3$, Disagree $(D)=2$, and Strongly Disagree $(S D)=1$. The filled questionnaire copies were retrieved from the health workers at the various selected secondary healthcare institutions by the researcher/ assistant after two weeks of administration. The data collected were analyzed using descriptive statistics of means and standard deviations. In the test of the hypothesis stated, one-way analysis of variance (ANOVA) was used. 


\section{Results}

The data analysis involves the use of means and standard deviations; this was based on the interval scale of measurement which quantified the data collected. Conclusion of the items was based on the mid-point along the four points interval scale. The mid-point used in the study is 2.5 , the value (2.5) stands for the least level of agreement on the scale while aggregate mean lower than 2.5 could thus be regarded as disagreement. The research hypothesis involved in the study was tested and analyzed with one-way analysis of variance (ANOVA) at 0.05 level of significance.

\begin{tabular}{|c|c|c|c|}
\hline $\mathbf{S} / \mathbf{N}$ & Availability of VIA requirements & Mean & Standard deviation \\
\hline 1. & $\begin{array}{l}\text { VIA supplies are present in the hospitals to screen } \\
\text { cervical cancer }\end{array}$ & 2.1018 & 0.82660 \\
\hline 2. & $\begin{array}{l}\text { There is an efficient system to ensure that the } \\
\text { hospitals do not run out of stock }\end{array}$ & 2.0000 & 0.69201 \\
\hline 3. & $\begin{array}{l}\text { Cost can be s significant factor to availability of } \\
\text { VIA requirement }\end{array}$ & 2.3085 & 0.86892 \\
\hline 4. & $\begin{array}{l}\text { There is adequate means of transportation of } \\
\text { available VIA requirements to the hospitals }\end{array}$ & 1.9752 & 0.74706 \\
\hline 5. & $\begin{array}{l}\text { There is enough equipments for providing VIA } \\
\text { screening in the hospitals }\end{array}$ & 1.9857 & 0.77122 \\
\hline 6. & Post-VIA management is available in the hospital & 1.9856 & 0.72087 \\
\hline 7. & $\begin{array}{l}\text { There is good referral system in the hospitals for } \\
\text { positive cases }\end{array}$ & 2.2403 & 0.91415 \\
\hline 8. & $\begin{array}{l}\text { The government provides free VIA screening } \\
\text { services in the hospitals }\end{array}$ & 1.9431 & 0.70480 \\
\hline 9. & $\begin{array}{l}\text { VIA requirements are only present in same } \\
\text { selected hospitals in the state }\end{array}$ & 2.4912 & 0.91009 \\
\hline 10. & $\begin{array}{l}\text { The VIA requirements are presents in medical } \\
\text { equipment stores in the state }\end{array}$ & 2.3286 & 0.86794 \\
\hline & Aggregate mean score & 2.1458 & 0.52065 \\
\hline
\end{tabular}

Table 1, showed an aggregate mean of 2.1458 which is less than the decisive mean of 2.5.Thus it indicates that VIA requirements are not available in secondary healthcare institution of kaduna state to screen for cervical cancer.

Table 2: Summary of ANOVA of age, professional category, years of working experience and secondary healthcare institutions in the provision of VIA requirement.

\begin{tabular}{llllll}
\hline Source & Sumof square & Df & Mean square & F-value & Sig. \\
\hline & & & & & \\
Secondary health care & & & & & 0.000 \\
institutions & 9.271 & 4 & 2.318 & 6.320 & \\
Between groups & 104.892 & 286 & 0.367 & & \\
Within groups & 114.163 & 290 & & \\
Total & & &
\end{tabular}

$($ F-Critical $=2.37, p<0.05)$

Table 2 above, shows a significant difference between the secondary healthcare institutions in the provision of VIA requirements for cervical cancer screening. The calculated F- value (6.320) is higher than the critical value of (2.37) at the same degree of freedom and significance level (p) obtained in the test is lower than the fixed level of $0.05(\mathrm{p}<0.05)$ 
Assessment Of Availability Of Visual Inspection With Acetic - Acid (Via) Requirements For Cervical

Table 3:Summary of post-hoc test (scheffe) of secondary healthcare institutions on the provision of VIA requirement for cervical cancer screening in Kaduna State

\begin{tabular}{|c|c|c|c|c|c|}
\hline $\begin{array}{l}\text { Dependent } \\
\text { variable }\end{array}$ & (I) Name of organization & $\begin{array}{l}(\mathrm{J}) \quad \text { Name } \\
\text { organization }\end{array}$ & $\begin{array}{l}\text { Mean difference (I- } \\
\text { J) }\end{array}$ & Standard Error & Sig. \\
\hline & & Gambo sawaba & -.40766 & .11389 & .124 \\
\hline & Barau Dikko & M.I.B.A & .29418 & .16303 & .916 \\
\hline & & Ikara & .19296 & .17102 & .937 \\
\hline & & Kafanchan & $-.41533^{*}$ & .10014 & $.031 *$ \\
\hline & & Kauru & $-.32332 *$ & .18053 & $.920 *$ \\
\hline & & Kachia & -.11439 & .14035 & 1.000 \\
\hline & & Barau Dikko & -.06316 & .07452 & .999 \\
\hline & & Birnin-gwari & $-.17954^{*}$ & .13449 & $.987 *$ \\
\hline & Dantsoho & Gambo sawaba & -.47082 & .11623 & .041 \\
\hline & & M.I.B.A & $.23102^{*}$ & .16466 & .987 \\
\hline
\end{tabular}

\begin{tabular}{|c|c|c|c|c|c|}
\hline $\begin{array}{l}\text { Dependent } \\
\text { variable }\end{array}$ & (I) Name of organization & (J) Name of organization & $\begin{array}{l}\text { Mean difference (I- } \\
\text { J) }\end{array}$ & Standard Error & Sig. \\
\hline & & Ikara & $-.35612 *$ & .17259 & $.832 *$ \\
\hline & & Kafanchan & -.47849 & .10280 & .007 \\
\hline & & Kauru & -.38648 & .18202 & .807 \\
\hline & & Kachia & $-.17755^{*}$ & .14226 & $.991 *$ \\
\hline & & Barau Dikko & .11637 & .13247 & .999 \\
\hline & & Dantsoho & .17954 & .13449 & .987 \\
\hline & Birnin-gwari & Gambo sawaba & -.29129 & .15971 & .911 \\
\hline & & M.I.B.A & $.41056^{*}$ & .19776 & $.827^{*}$ \\
\hline & & Ikara & $-.17659^{*}$ & .20441 & $.999 *$ \\
\hline & & Kafanchan & -.29896 & .15021 & .859 \\
\hline & & Kauru & -.20694 & .21243 & .999 \\
\hline & & Kachia & $.00198^{*}$ & .17954 & $1.000^{*}$ \\
\hline & & Barau Dikko & .40766 & .11389 & .124 \\
\hline & & Dantsoho & $.47082^{*}$ & .11623 & $.041 *$ \\
\hline & Gambo sawaba & Birnin-gwari & $.29129^{*}$ & .15971 & $.911^{*}$ \\
\hline & & M.I.B.A & .70184 & .18583 & .080 \\
\hline & & Ikara & .11470 & .19289 & 1.000 \\
\hline & & Kafanchan & $-.00767 *$ & .13411 & $1.000^{*}$ \\
\hline & & Kauru & .08434 & .20137 & 1.000 \\
\hline & & Kachia & .29327 & .16630 & .926 \\
\hline & & Barau Dikko & -.29418 & .16302 & .916 \\
\hline & & Dantsoho & $-.23102 *$ & .16466 & $.982 *$ \\
\hline & M.I.B.A & Birnin-gwari & $-.41056^{*}$ & .19776 & $.827^{*}$ \\
\hline & & Gambo sawaba & -.70184 & .18583 & .080 \\
\hline & & Ikara & -.58714 & .22541 & .561 \\
\hline & & Kafanchan & $-.70951^{*}$ & .17773 & $.047 *$ \\
\hline & & Kauru & -.61750 & .23270 & .534 \\
\hline & & Kachia & $-.40857^{*}$ & .20312 & $.852^{*}$ \\
\hline & & Barau Dikko & $.29296^{*}$ & .17102 & $.937^{*}$ \\
\hline & & Dantsoho & .35612 & .17259 & .832 \\
\hline & Ikara & Birnin-gwari & .17659 & .20441 & .999 \\
\hline & & Gambo sawaba & $-.11470 *$ & .19289 & $1.000 *$ \\
\hline+ & & M.I.B.A & .58714 & .22541 & .561 \\
\hline & & Kafanchan & -.12237 & .18510 & 1.000 \\
\hline & & Kauru & -.03036 & .23838 & 1.000 \\
\hline & & Kachia & $.17857^{*}$ & .20960 & $.999 *$ \\
\hline & & Barau Dikko & $.41533^{*}$ & .10014 & $.031 *$ \\
\hline & & Dantsoho & .27849 & .10280 & .007 \\
\hline & Kafanchan & Birnin-gwari & .29896 & .15021 & .859 \\
\hline & & Gambo sawaba & $.00767^{*}$ & .13411 & $1.000^{*}$ \\
\hline & & M.I.B.A & .70951 & .17773 & .047 \\
\hline & & Ikara & $.12237 *$ & .18510 & $1.000 *$ \\
\hline & & Kauru & .09201 & .19392 & $1.000 *$ \\
\hline & & Kachia & .30094 & .15720 & .885 \\
\hline & & Barau Dikko & .32332 & .18053 & .920 \\
\hline & & Dantsoho & $.38648^{*}$ & .18202 & $.807 *$ \\
\hline & Kauru & Birnin-gwari & .20694 & .21243 & .999 \\
\hline & & Gambo sawaba & -.08434 & .20137 & 1.000 \\
\hline & & M.I.B.A & .61750 & .23270 & .534 \\
\hline & & Ikara & $.03036^{*}$ & .23838 & $1.000 *$ \\
\hline & & Kafanchan & $-.09201 *$ & .19392 & $1.000^{*}$ \\
\hline & & Kachia & .20893 & .21743 & .999 \\
\hline & & Barau Dikko & .11439 & .14035 & 1.000 \\
\hline
\end{tabular}


Assessment Of Availability Of Visual Inspection With Acetic - Acid (Via) Requirements For Cervical

\begin{tabular}{|l|l|l|l|l|l|}
\hline & & Dantsoho & $.17755^{*}$ & .14226 & $.991^{*}$ \\
\hline & Kachia & Birnin-gwari & -.00198 & .17954 & 1.000 \\
\hline & & Gambo sawaba & $-.29327^{*}$ & .16630 & $.926^{*}$ \\
\hline & M.I.B.A & $.40857^{*}$ & .20312 & $.852^{*}$ \\
\hline & Ikara & -.17857 & .20960 & .999 \\
\hline & Kafanchan & -.30094 & .15720 & .885 \\
\hline & Kauru & $-.20893^{*}$ & .21743 & $.999^{*}$ \\
\hline & & Dantsoho & .19330 & .08482 & .736 \\
\hline
\end{tabular}

The mean is significant at 0.05 level

Table 4: Distribution of Secondary HealthCare Institutions and numbers of Nurses working in the facilities

\begin{tabular}{|c|c|c|c|c|c|}
\hline $\mathbf{S} / \mathbf{N}$ & Secondary healthcare institutions & L.G.A & Senatorial zone & $\begin{array}{l}\text { Numbers } \\
\text { of nurses }\end{array}$ & Selected \\
\hline $1 *$ & Barau Dikko Specialist Hospital & Kaduna North & Kaduna central & 219 & 100 \\
\hline $2 *$ & Yusuf Dantsoho memorial hospital & Kaduna south & Kaduna central & 179 & 82 \\
\hline 3 & Dr. Awan Kakuri Kaduna & Kaduna south & Kaduna central & 150 & \\
\hline 4 & General hospital Kawo Kaduna & Kaduna north & Kaduna central & 40 & \\
\hline 5 & General hospital Sabon Tasha & Kaduna south & Kaduna central & 50 & \\
\hline 6 & General hospital Rigasa & Igabi & Kaduna central & 13 & \\
\hline $7 *$ & Hajiya Gambo Sawaba memorial Hospital & Zaria & Northern Kaduna & 56 & 26 \\
\hline $8 *$ & Major Ibrahim memorial hospital & Sabon-Gari & Northern Kaduna & 25 & 11 \\
\hline 9 & General hospital Giwa & Giwa & Kaduna central & 26 & \\
\hline 10 & General hospital Hunkuyi. & kudan & Northern Kaduna & 20 & \\
\hline 11 & General hospital Makarfi & Makarfi & Northern Kaduna & 23 & \\
\hline $12 *$ & General hospital Ikara & Ikara & Northern Kaduna & 19 & 9 \\
\hline $13 *$ & General hospital, Kauru & Kauru & Southern Kaduna & 17 & 8 \\
\hline 14 & General hospital Pambegua. & kubau & Northern Kaduna & 14 & \\
\hline 15 & General hospital Saminaka. & lere & Northern Kaduna & 49 & \\
\hline $16^{*}$ & General hospital Kafanchan. & Jama'a & Southern Kaduna & 73 & 33 \\
\hline 17 & General hospital Zangon Kataf & Zangon-kataf & Southern Kaduna & 17 & \\
\hline 18 & General hospital Gwantu. & sanga & Southern Kaduna & 24 & \\
\hline $19 *$ & General hospital Kachia & Kachia & Southern Kaduna & 32 & 15 \\
\hline 20 & General hospital Kagarko & Kagarko & Southern Kaduna & -- & \\
\hline \multirow[t]{2}{*}{$21 *$} & Jibril Mai-Gwari Memorial Hospital. & Birnin-gwari & Kaduna central & 35 & 16 \\
\hline & Total & & & 1081 & 300 \\
\hline
\end{tabular}

*Shows selected secondary healthcare institutions.

\section{Discussion}

The researchers examined the availability of visual inspection with acetic acid (VIA) requirement among health workers in secondary healthcare institutions of Kaduna State.

In the course of this study, it has been established that VIA requirements are not available for health workers in the secondary healthcare institutions for cervical cancer screening as indicated in table 1 with an aggregate mean score of (2.1458). one of such basic areas of inadequate VIA requirements in the secondary healthcare institutions were the subjects that agreed that there is no efficient system to ensure that the hospitals do not run out of stock if available. Also there is poor referral system in the hospitals in case of positive cases identified during the screening procedure as indicated in item (7). To worsen the inadequacy of VIA requirements in the hospitals, the medical equipment stores do not possess the supplies as perceive by the health workers in the study (item 10). These findings are supported by USAID (2010), which stated that cervical cancer screening services with acetic acid staining (VIA) are available only in research settings and/or referral centres of Rwanda, Nigeria and Cote d' Ivore but not available at multiple sites/levels of care throughout the country. Although the study shows that VIA requirements are not present in the hospitals to screen for cervical cancer, it contradicts the statements of Gaffikin, Mcgrath, Arbyn, Blumenthal (2007) whom stated that the pap smear remains the most common screening test for cervical cancer, many developing countries do not have adequate resources to implement cytology based prevention programme. An alternative, low-cost test, visual inspection using acetic acid (VIA), has emerged for use in developing countries, Nigerian inclusive where the resources are available. Even though the VIA requirements are not available in the hospitals, it does not mean that the government cannot afford to provide it in the hospitals in surplus within the state. In the test of the hypothesis stated, a significant difference was observed among the secondary healthcare institution in the provision of VIA requirements for cervical cancer screening, thus the null hypothesis was rejected. USAID (2010) stated that the choice of screening test usually depends on the resources available. Furthermore, many developing countries are now using the single visit approach which combines detection of lesions using visual 
inspection with acetic acid followed by immediate treatment if necessary. Therefore, non availability of VIA requirements for screening cervical cancer within the study area encourages development of cervical cancer due to delay in detection of it.

\section{Conclusion}

It can be concluded that VIA requirement are not available in the secondary health care institutions of Kaduna- state.

\section{Recommendation}

It is therefore recommended that the hospital management should make provision of VIA requirements through a strategized fund raising so that they can be available in the hospitals in order to tackle delay in detection that could lead to high incidence of cervical cancer.

\section{References}

[1]. Alliance for Cervical Cancer Prevention (2004a). Planning and implementing cervical cancer prevention and control programs. A manual for Managers settle.(2004)pp 20-23.

[2]. Dim,C.C.(2012).Improving cervical screening in Nigeria; A review of the basics of neoplasm and cytology practice. Nigerian journal of clinical practice. Volume 15(3) pp 247-252. Available at http:// www.njcp online.com/text.asp? retrieved on 5/3/2013

[3]. Evaluation of Cervical cancer in Nigeria (2013). Oxbridge writers, brand of all answers ltd. No 4964706.VAT NO:842417633. Available at http://www.oxbridge writers. Com/essays/health/evaluation-of-cervical-cancer-in-nigeria.php\# ixZZ2QFFdY61Y

[4]. Ferlay,J., Bray, F., Pisani,P., and Parklin, D. M.(2013). Cancer incidence, mortality and prevalence worldwide. GLOBACOM,IARC Cancer Base No.5 Version 2.0, Lyon, IARC Press

[5]. Gaffikin L., Mcgrath J., Arbyn M., and Blumenthal P.D (2007). Visual inspection with acetic acid as a cervical cancer test; accuracy validated using latent class analysis. BMC medical research methodology (2007) (vol) 10, pp 7-36.

[6]. Gupta,S .(2011). A Comprehensive text book of obstetrics and Gynaecology. New Delhi. Jaypee Brothers Medical Publishers (p) ltd

[7]. Ibrahim, A., Rasch, V., Pukkala, E., and Aro, A.R.(2004). Cervical cancer risk factors and feasibility of visual inspection with acetic acid screening in sudan. International Journal of womens health (2004). (Vol) 6 pp 234-240.

[8]. USAID (2010).PEPFAR cervical cancer prevention and screening regional workshop report. USAID. Washington.

[9]. Yamane, T(1967)."Statistics: an introductory analysis". Newyork : Harper and Row. 